Article

\title{
The Torah Ark of Arthur Szyk
}

\section{Susan Nashman Fraiman}

Rothberg International School, The Hebrew University of Jerusalem, Jerusalem 9190501, Israel; susannf@gmail.com

Received: 14 April 2020; Accepted: 13 May 2020; Published: 19 May 2020

Abstract: This paper discusses the design and symbolism of a hitherto unpublished work by the artist Arthur Szyk (1894-1951), an ark for the Torah which he designed for the Forest Hills Jewish Center of Queens, New York, and which was dedicated in 1949. The Torah Ark is the central focus of all synagogue worship. Szyk's ark is unique in its multiplicity of symbols and texts, which was at odds with the modernist idiom of post-World War II synagogue architecture. This research, which also brings previously unpublished material, analyzes the possible sources for the work and its distinctive message, which is exceptional in the world of modern contemporary Jewish art.

Keywords: Arthur Szyk; synagogue; Jewish art; tribes; freedom; Ben-Zion Bokser

\section{Introduction}

In the last few years, interest in the art of Arthur Szyk has taken a dramatic turn. From an artist who was popular in the 1940s, blacklisted in the early 1950s, and often associated with kitsch and a reactionary art style in the late 20th century (Mendelsohn 2010, p. 324), Szyk has been the subject of several monographs ${ }^{1}$ and exhibits ${ }^{2}$ in the last two decades. A huge collection of his work, amassed by a private collector, was recently donated to the Magnes Collection of Jewish Art and Life in Berkeley. Known as The Taube Family Arthur Szyk Collection, it contains hundreds of works, many of them unpublished, including sketches for book illustrations, posters, and caricatures. Interestingly enough, one of Szyk's most unique creations, a Torah Ark (Figure 1) he designed for the Forest Hills Jewish Center of Queens, NY, has never been studied. The ark is an unusual combination of traditional symbols with new elements, and this article discusses its history and unique iconography.

1 See (Ansell 2004) and a scholarly reevaluation of his famous Haggadah, (Sherwin and Ungar 2008).

2 To mention a few in the last twenty years: Arthur Szyk: Artist for Freedom at the Library of Congress, 9 December 1999-6 May 2000. https://www.loc.gov/exhibits/szyk/, accessed on 8 December 2019; The Art and Politics of Arthur Szyk, United States Holocaust Memorial Museum, 10 April 2002-14 October 2002; https:/www.ushmm.org/exhibition/szyk/, accessed on 8 December 2019; and the exhibit at the New York Historical Society, 15 September 2017-21 January 2018; https://www. nyhistory.org/exhibitions/arthur-szyk-soldier-art, accessed on 8 December 2019. 


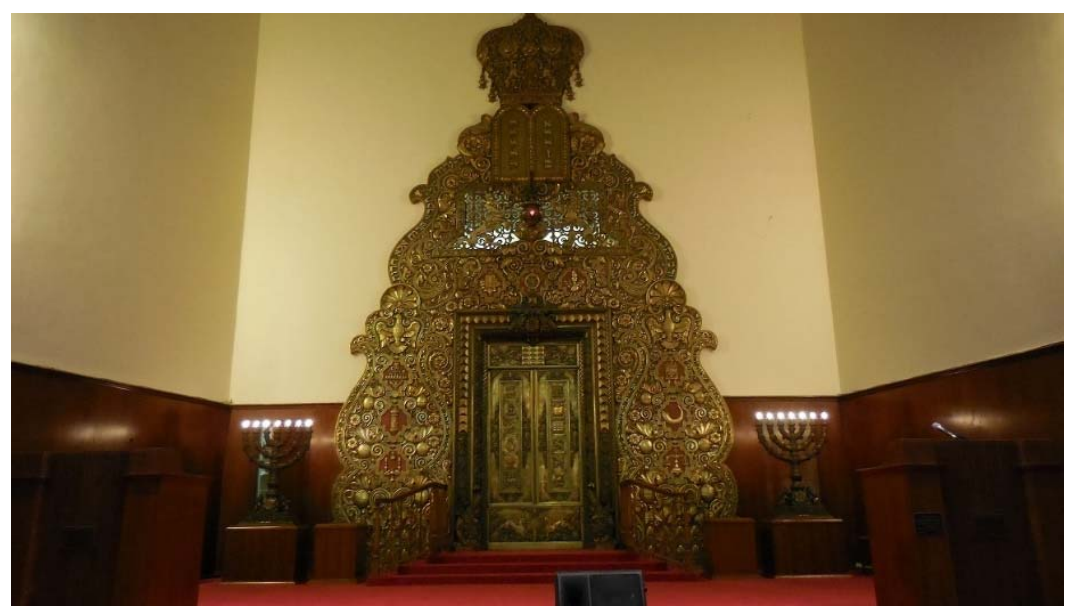

Figure 1. Torah Ark and bimah, Forest Hills Jewish Center, 1949 (photographed 2017 by the author).

\section{The Artist}

The artist Arthur Szyk (1894-1951) was born and raised in Lodz, Poland. Szyk studied art in Cracow and Paris and traveled to Palestine in 1914 (Luckert, p. 9; Ansell 2004, p. 20) and Morocco in 1925 (ibid., p. 44). Szyk is best known for his oft-reproduced Haggadah. ${ }^{3}$ The Szyks, who had been living in Paris, moved to London in 1937, to work on the publication of the Haggadah. In the end, the Haggadah, which was printed on parchment, was dedicated to King George the VI (Ansell 2004, p. 97; Cohen 1946/1947, p. 73), and published with an introduction by Cecil Roth. At the same time, Szyk was also drawing anti-fascist cartoons for the British Press. The outbreak of the war made the complete publication of the Haggadah difficult, so the peripatetic Szyks moved to Canada in 1940, where they stayed for six months. ${ }^{4}$ At the end of 1940, the Szyks moved to the New York City area, where Szyk immediately immersed himself in both the political and artistic scene of the US. He had several high-profile public exhibitions of his work (Ansell 2004, p. 121) and continued his anti-fascist activity in art, mainly through caricature. He published a book of his caricatures in 1941, and his caricatures also appeared in a wide variety of American publications, mercilessly lampooning both the Nazis and the Japanese. By 1942, his name had already appeared on the cover of The American Hebrew as one of the notable American Jews of 1941, along with Eddie Cantor, Rabbi David de Sola Pool, Louis Finkelstein, and Israel Goldstein, to name a few others. ${ }^{5}$ In 1942, the Haggadah was exhibited at the Jewish Theological Seminary. ${ }^{6}$

\section{The Forest Hills Project}

Szyk likely got involved with the project in Forest Hills through one of its prominent members, Herman Jaffe. ${ }^{7}$ In fact, a copy of the original Haggadah, signed by both Szyk and Cecil Roth, with a

3 The Haggadah was published in 1940 in England (Roth 1969, p. 50). According to the Jewish Theological Seminary announcement (Alfred Werner collection, M.E. Grenander Department of Special Collections \& Archives University at Albany, SUNY archive), some 240 copies were printed, of which 115 were in the United States. The Haggadah was printed multiple times in both Israel and the United States. A recent facsimile was reissued, with translation and commentary by Byron L. Sherwin with Irvin Ungar, in 2011 (Szyk 2011).

4 They lived in London from 1937 until 1940 (Ansell 2004, pp. 117-19).

5 Cover of The American Hebrew "For Better Understanding between Christians and Jews", 16 January 1942.

6 The Haggadah was put on display at the Jewish Theological Seminary in the spring of 1942, as mentioned in the Flatbush Jewish Center Bulletin of the same year, undated (Alfred Werner collection, M.E. Grenander Department of Special Collections \& Archives University at Albany, SUNY archive). This exhibit does not appear in the list that appears at the end of (Ungar 2017a).

7 Irvin Ungar in discussion, December 2018. Jaffe was an art printer who lived in Forest Hills, so it is not surprising that he would have known Szyk. https://www.nytimes.com/1971/05/08/archives/herman-jaffe-77-printed-art-stamps.html, 
dedication to the Jaffes, is in the collection of the synagogue (Figure 2). In May 1943, Szyk's Haggadah was exhibited at the National Conference for Palestine. One of the speakers was the prominent American Reform Rabbi Abba Hillel Silver (Ansell 2004, p. 129). Szyk was a Zionist, interestingly enough, of the Revisionist persuasion (ibid., p. 39). In 1946, Silver commissioned Szyk to design stained-glass windows for the Temple Tifereth Israel, his synagogue in Cleveland, in memory of congregants who died fighting in World War II. Szyk depicted three Biblical Heroes: Gideon, Samson, and Judah Maccabee, in their memory (ibid., p. 195). ${ }^{8}$ By that time, Szyk was already in touch with the Forest Hills congregation-his Haggadah was exhibited there in March 1945, and subsequently, various works of his appeared in the synagogue newsletter. ${ }^{9}$ During this period, the charismatic Conservative rabbi of Forest Hills, Ben Zion Bokser (1907-1984) (Carmin 1955, pp. 631-32), was serving as a military chaplain at Camp Myles Standish in Taunton, Massachusetts, a jumping-off point for troops fighting in Europe, ${ }^{10}$ and from February 1944, the congregation was being led by a student rabbi at the Jewish Theological Seminary, Jacob Pressman (1919-2015) (Pressman 2001, p. 21). At the war's end, the synagogue's board, no doubt in conjunction with the rabbi, started a campaign for a new larger building to house the postwar booming Jewish community. In September 1945, there were 615 families that were members of the community, and their old building no longer met their needs.

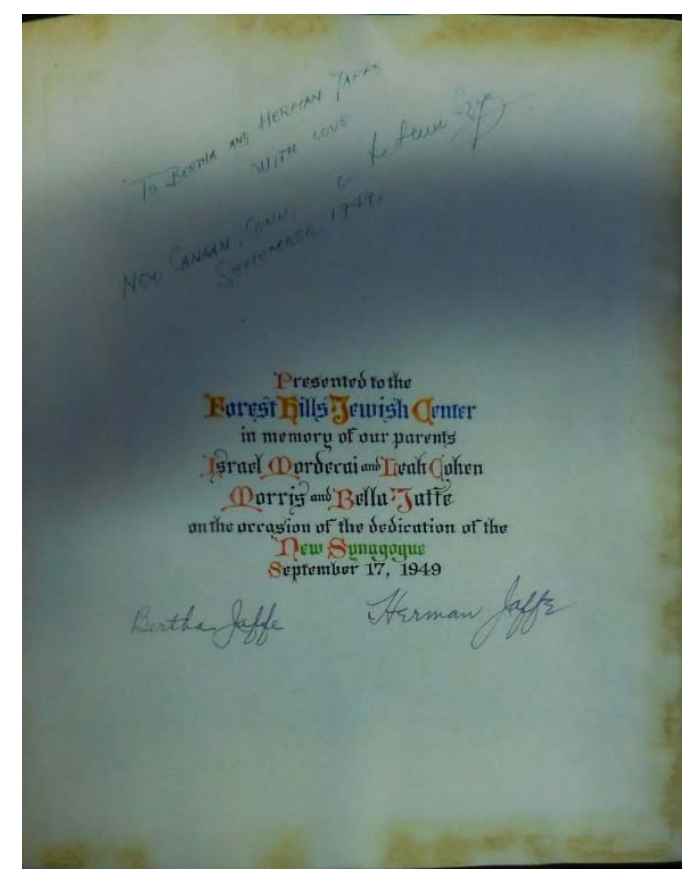

Figure 2. Dedication of the Haggadah by Szyk to the Jaffes.

The synagogue that was built, designed by Joseph Furman, has an exterior of crab orchard stone, brick facing, and limestone trim. ${ }^{11}$ Original drawings for the plan of the ark are still in the collection

accessed on 22 December 2019; in this obituary, it is mentioned that he printed stamps for Liberia, and Szyk seems to have designed them (Ungar 2017a, p. 215, plate 176).

8 The Temple was converted into an arts center in 2010, since the community has a new home. https://www.clevelandjewishnews.com/ archives/the-temple-unlocks-key-to-the-past/article_5d9fc945-9f21-5a76-854b-a5af426a89ed.html, accessed on 6 December 2019. 9 Forest Hills Home News, March 1945, vol. 1, no. 4, 2, JTA, Bokser archives box 15/3.

10 Correspondence Ben Zion Bokser Rabbinical Papers, The Library of the Jewish Theological Seminary, New York, NY, ARC.1000.026, (Box 15) (Bernstein 1945, p. 180); Bokser was inducted in 1944 and released in 1946. All of his service was stateside.

11 Mentioned briefly by Wischnitzer (1955, p. 165). The synagogue, designed on "very plain lines", dispensed with the flexible plan which was coming into its own at that time, and "[i]t was felt, before long, however, that the prayer hall needed spiritual content, color, emotional stimulation". 
of the synagogue: a drawing for the sides of the ark (Figure 3), a drawing of the doors (Figure 4), a drawing of the Ner Tamid (Figure 5), a drawing of the menorot, (Figure 6), and a drawing for a parochet or a valence by Szyk that was never executed (Figure 7). The cornerstone was set in 1947 and dedicated on Sept 18, 1949, in the presence of local dignitaries, including the mayor of New York, Thomas O'Dwyer. The dedication even made it to the Herald Tribune, one of the important New York newspapers of the time. ${ }^{12}$

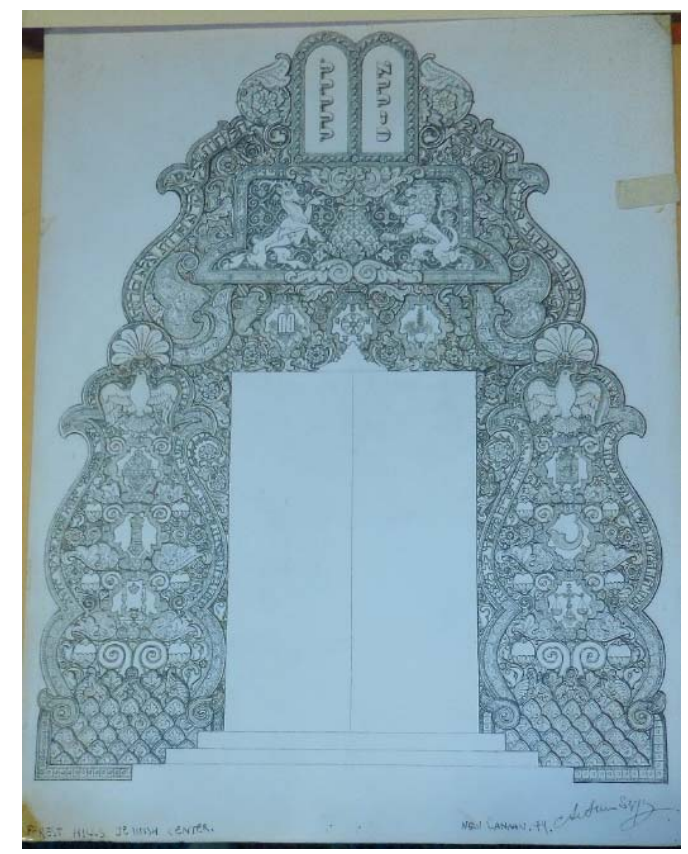

Figure 3. Arthur Szyk, ink sketch for the sides of the ark, 1949.

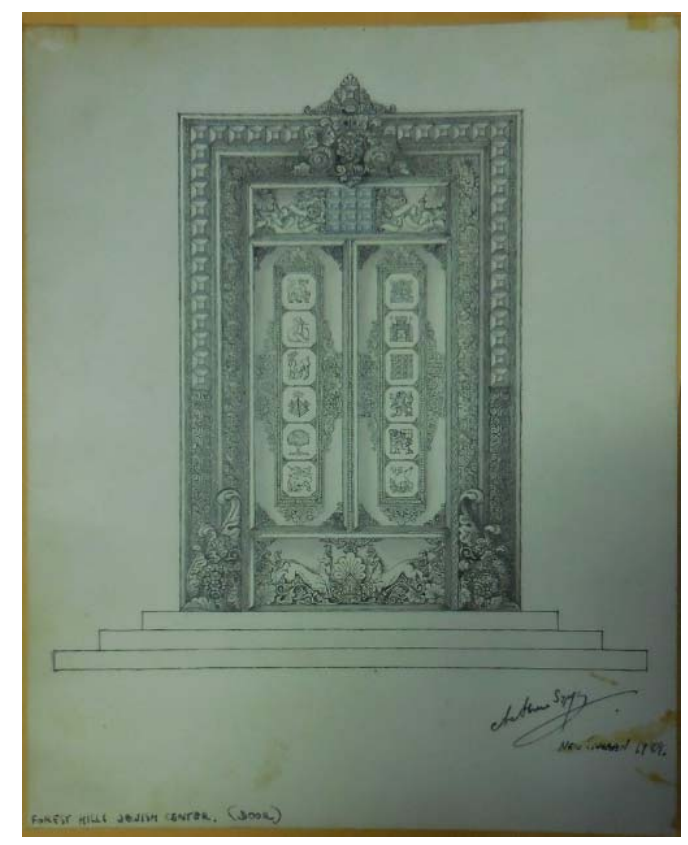

Figure 4. Arthur Szyk, ink sketch for the ark doors, 1949.

12 "New Forest Hills Synagogue and Jewish Center Is Opened: Dedicatory Service in New Synagogue in Forest Hills", New York Herald Tribune (1926-1962), 19 September 1949, p. 17. 


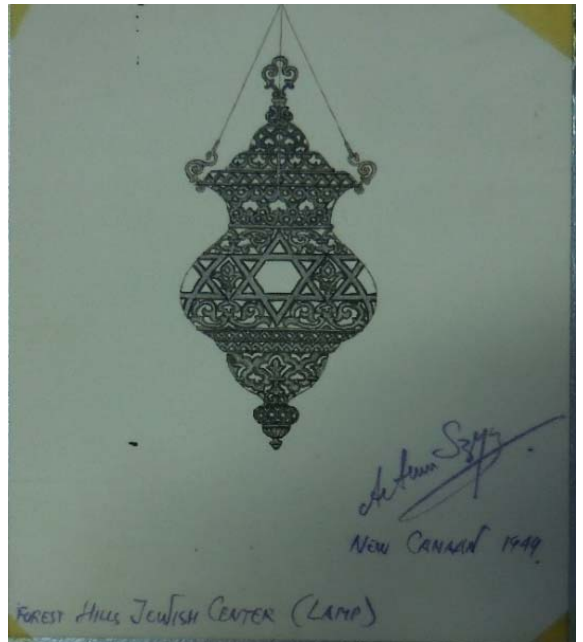

Figure 5. Arthur Szyk, ink sketch for the Ner Tamid, 1949.

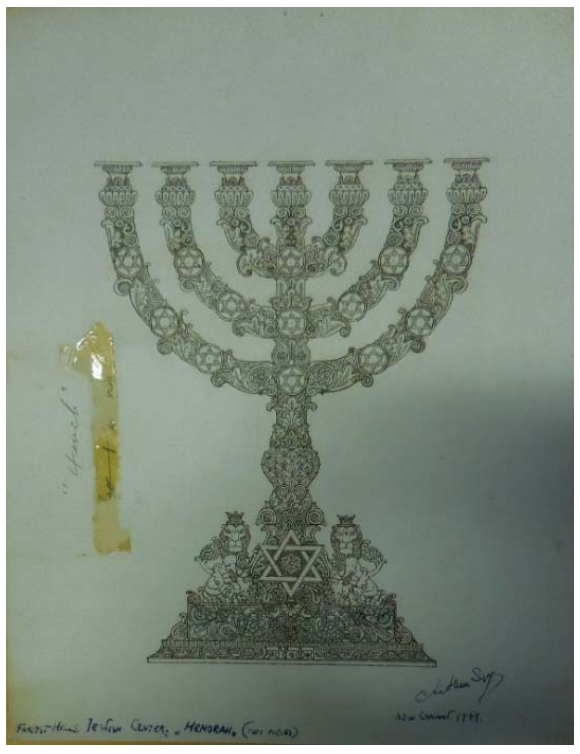

Figure 6. Arthur Szyk, ink sketch for the Menorah, 1949.

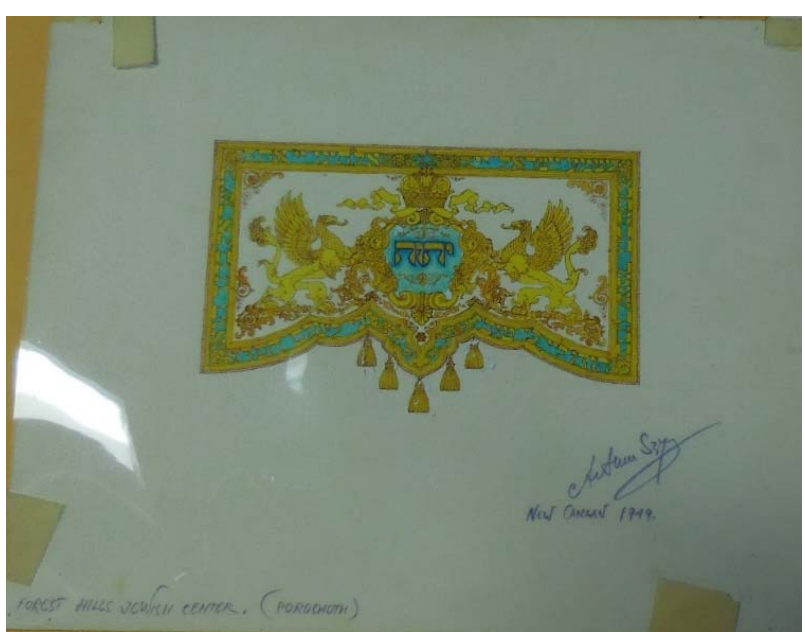

Figure 7. Arthur Szyk, ink sketch for the "Parochuth [sic]", 1949. 


\section{The Ark}

The ark stands close to $9 \mathrm{~m} \mathrm{high}^{13}$ and is made from cast and painted plaster, with the exception of the inner grill, menorot, (measuring $1.2 \mathrm{~m}$ high and $1 \mathrm{~m}$ wide) (Figure 8 ) and the ark doors, which are cast bronze. ${ }^{14}$ The grill was left open because behind it sat the choir. While the shape is symmetrical, the right and left sides are not identical. The entire façade of the ark is filled with decoration-flowers, acorn designs, acanthus leaves, scrolls, and vines. It is possible to divide the ark into three main parts: on each side, a paisley-shaped area, bordered by text that contains three elements relating to Jewish holidays or practice; the bronze ark doors with the symbols of the tribes; and the upper area, surmounted by a crown and also bordered with a text. The ark should be interpreted from right to left, as that is the order of the verses that appear on its flanks, and of course, the way the Hebrew language is read.

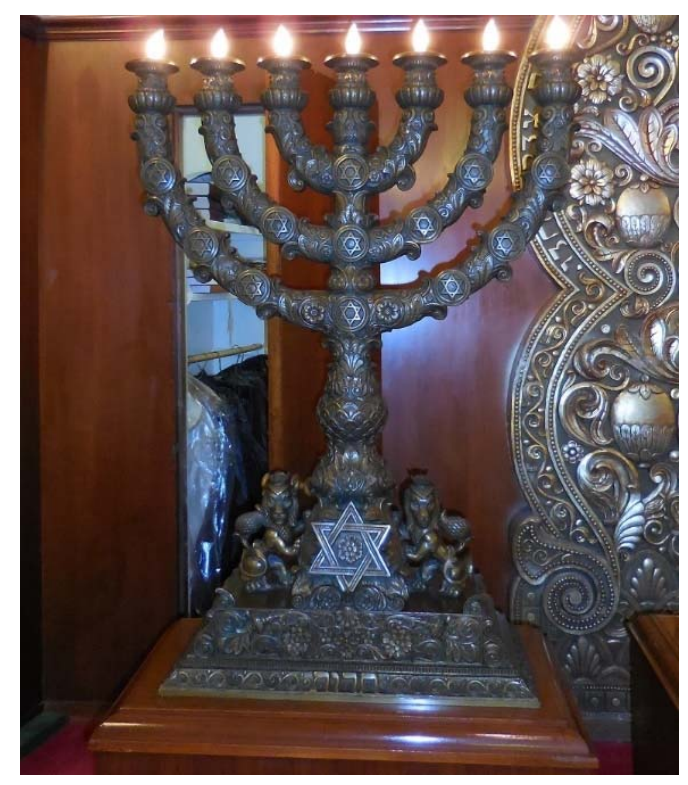

Figure 8. Menorah, Forest Hills Jewish Center.

On the right side (Figure 9a) is a scale, above which is a shofar, and above that, a Torah scroll, symbolizing, respectively, the Day of Atonement, the New Year, and Simchat Torah. ${ }^{15}$ A bird facing outward, above which is a palmette, completes that part of the ark.

The text around these elements reads as follows, starting at the level of the scale:

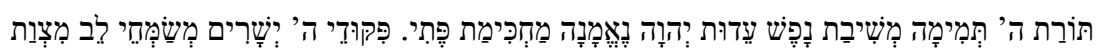

The law of the LORD is perfect, restoring the soul; the testimony of the LORD is sure, making wise the simple. The precepts of the LORD are right, rejoicing the heart ...

The second half of verse 9 continues on the left side, followed by verse 10 . These texts surround the following motifs (Figure 9b): a two-branched candlestick, with two challot and a kiddush goblet in front of them; the scroll case of a Megillah; and, above that, an oil lamp for Hanukkah. The text starts at the level of the candlesticks and works upward, around the bird atop the Hanukkah lamp, and curls down the outer left side of the ark.

1330 feet tall, according to Israelowitz (1992, p. 129).

14 The Forest Hills Jewish Center 1931-1981, 1981, unpaged, in the collection of the synagogue.

15 From an explication of the ark in Bokser's papers at the Jewish Theological Seminary, "An Interpretation of Our Ark," Ben Zion Bokser Rabbinical Papers, The Library of the Jewish Theological Seminary, New York, NY, ARC.1000.026, (Box 17, Folder 5). 
[T] he commandment of the LORD is pure, enlightening the eyes. The fear of the LORD is clean, enduring forever; the ordinances of the LORD are true, they are righteous altogether. (Psalms 19, pp. 9-10) ${ }^{16}$

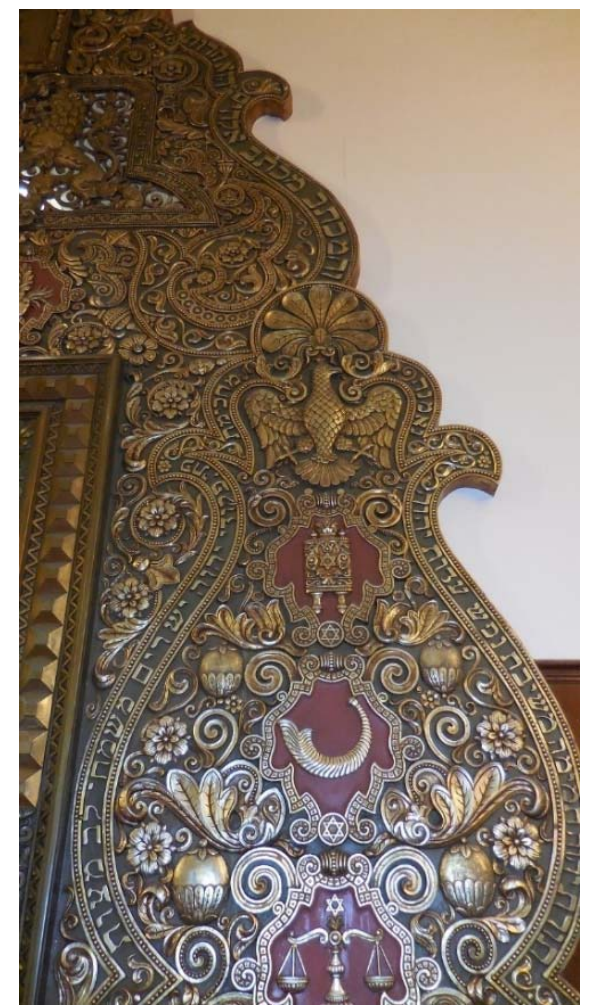

(a)

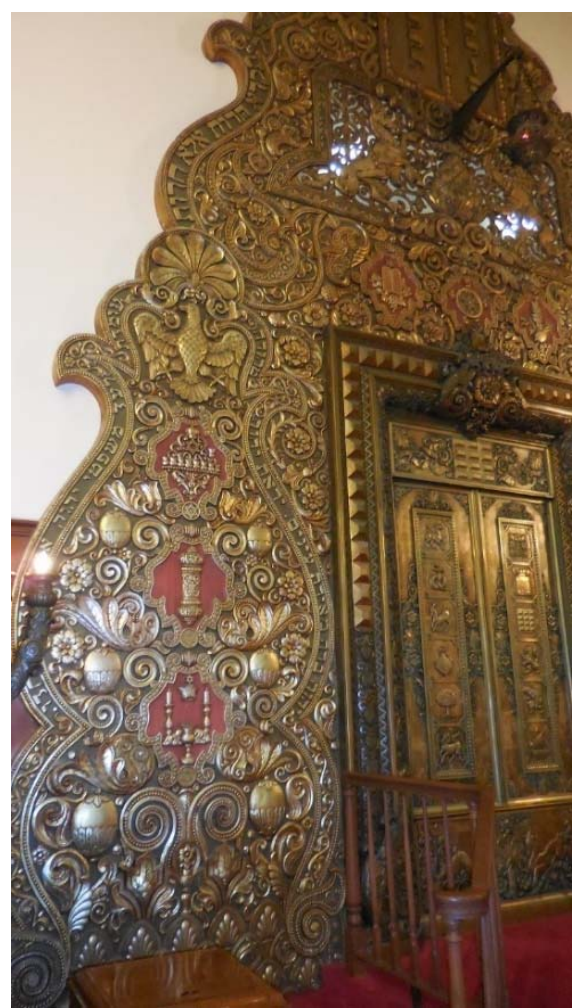

(b)

Figure 9. The right (a) and left (b) sides of the ark.

Below the central doors are two heraldic animals facing each other, reminiscent of the kid of the Passover hymn, Had Gadya (Sabar 2008a, pp. 148-49). In the center rectangular panel above the doors is a representation of the breast plate worn by the High Priest at the Temple services in Jerusalem. Above them (Figure 10), centered over the door, again reading from right to left, are a lulav and etrog; a round seder plate, topped by the Hebrew letter "פ" for Pesach (Passover) ${ }^{17}$ and flanked by four goblets; and the two tablets of the Ten Commandments surrounded by fruit. These are symbols of the three pilgrimage festivals according to their order in the Jewish year: Sukkot (Tabernacles), which occurs immediately after the Jewish New Year, in the month of Tishrei; Pesach (Passover) in the month of Nisan; and Shavuot (the holiday of the First Fruits and the Giving of the Law) in the month of Sivan. Above them, a rampant stag on the left and a rampant lion on the right face inward, to what appears to be a pinecone. At the base of the pinecone is a Star of David. Above them are the two Tablets of the Law, with the first letters of each of the Ten Commandments in Hebrew (Figure 11), reading from right to left. At the very top is an elaborate Torah crown. At the base of this crown are colored gems (glass), and above them are two rampant griffins. Bells hang from both sides of the crown. The crown is topped with a small knop. The verse that extends from the right upper border of the ark to the central motif of the crown and tablets reads as follows:

16 The texts are not vocalized, with the important exception of two words, as we shall see later.

17 This element also appears in the Haggadah. See (Sabar 2008a, pp. 54-55). 
The verse then continues down the left side:

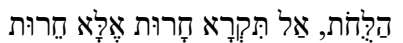

It appears that the entire verse is a commentary from the Ethics of the Fathers (6:2) to Exodus 32:16: "And the tablets were the work of God, and the writing was the writing of God, graven upon the tablets". The text of Ethics of the Fathers continues thus: "Read not harut [engraved] but herut [freedom] for none can be considered free except those who occupy themselves with the study of the Torah". This rabbinic play on words is caused by a change in the vocalization of the words, with a kamatz under the first het, and a tzere under the second. ${ }^{18}$

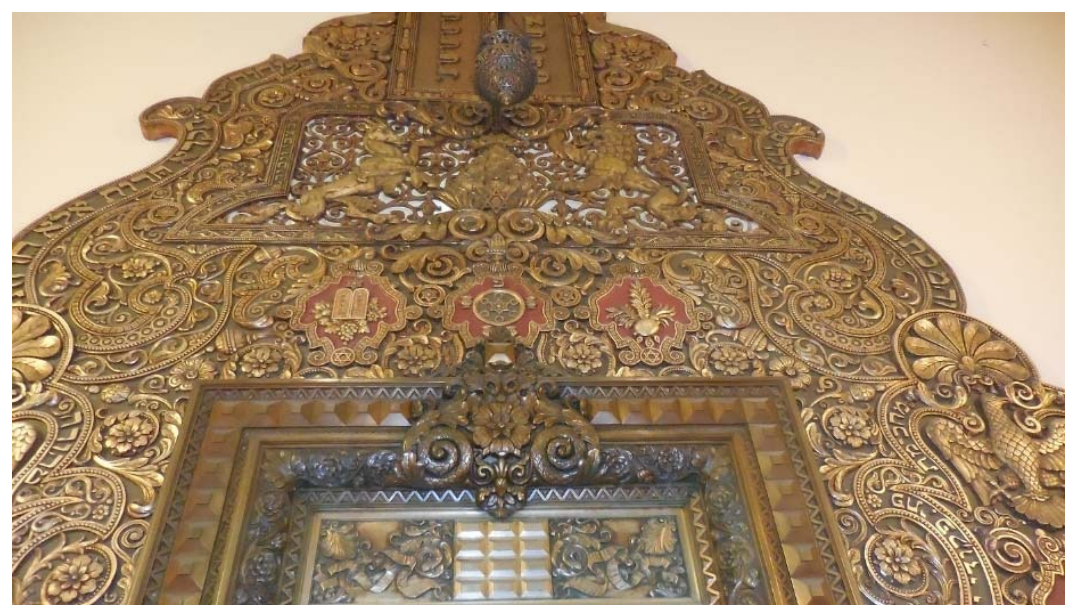

Figure 10. Central section over the ark, including part of the 39 "jewels".

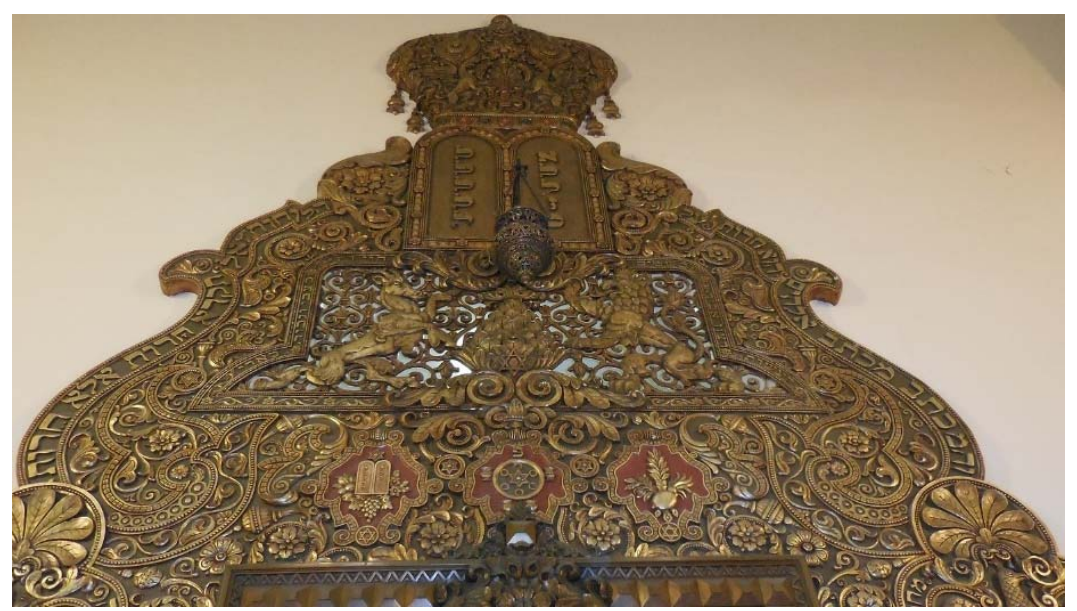

Figure 11. The upper part of the ark.

\section{The Iconography of the Ark}

This ark is a fascinating mix of traditional and innovative elements. Szyk incorporated many well-known elements of prewar European synagogue decoration. The crown atop the ark, the griffins, and the heraldic animals are all elements known from the Torah arks of prewar European synagogues.

18 The vowels appear on the verse on the ark to make the distinction-there is no vocalization in the other Hebrew verses on the ark. 
One of the upper texts around the inner cartouche (Figure 10) is an excerpt from a well-known verse from Ethics of the Fathers (Pirkei Avot) 5:20, and unlike the other verses, starts on the left.

הוי ..., רץ כצבי, וגבור כארי לעשות רצון אביך שבשמים

[Judah ben (son of) Taima said] be [bold as a leopard, light as an eagle], swift as a deer, and strong as a lion to do the will of your Father in Heaven.

This verse (abbreviated because only the deer and the lion are depicted), of course, surrounds the deer and the lion. Many of these traditional motifs from Eastern European arks have been recently been reproduced and researched in detail. ${ }^{19}$

How Szyk was exposed to these traditional elements is not clear. While many of these elements are common in Eastern European synagogues, there was no such synagogue in Lodz while Szyk lived there. The Jewish community of Lodz only really began to flourish in the 19th century, and there were no carved wooden arks there. Perhaps it was Szyk's later contact with the Jewish community of Lvov that influenced him, since, at one point, he planned to dedicate the Haggadah to them. ${ }^{20}$ At around the time Szyk was painting the works for the Haggadah, which were all done between 1934 and 1936 (Ungar 2008, p. 209), ${ }^{21}$ the Jewish community of Lvov built a new synagogue, the Tsori Gilad Synagogue, and had its walls richly painted. ${ }^{22}$ Among the painted elements are griffins holding a crown, also used by Szyk. Griffins appeared on many of the carved wooden Torah arks from Europe. ${ }^{23}$

\section{The Unique Iconography of Szyk}

Several elements in this ark are specific creations of Szyk's. Some are based on traditional motifs that have been adjusted by Szyk to fit his scheme. It is also clear that, in the design of this ark, Szyk drew heavily on his previous works, particularly the Haggadah. Szyk had already made use of many traditional motifs in the Haggadah of $1940,{ }^{24}$ and he incorporated them into the design of the ark. A few examples include the griffins and heraldic lions (Sabar 2008a, pp. 50-51); ${ }^{25}$ the two animals below the symbols of the tribes on the ark doors; and the design of the menorot on the bimah in front of the ark (Figure 8) already appeared in the Haggadah. ${ }^{26}$

The symbols used for the holidays, such as the seder plate and the Torah scroll, are Szyk's innovations and modernizations of earlier themes, which in the past would sometimes appear on ark curtains $^{27}$ rather than on the ark themselves.

One original element is the 39 "jewels" around the upper frame of the ark doors that stand for the 39 books of the Hebrew Bible. ${ }^{28}$ As mentioned above, on either side of the ark doors, and above the holiday motifs, are two birds, each facing outward. The ambience of the postwar era, and the hope that World War II would be the last war, no doubt influenced the choice of these two birds, which were

19 The motif of the crown is discussed by Yaniv (2017, pp. 104-11), and on arks 2, 4, 5, 6, 7, 9, and 11, in her appendix I; all four animals mentioned in Ethics of the Fathers 5:20 appear on the Torah ark from Kepno, 1816-1817 (Yaniv 2017, p. 262; Yaniv 2006, p. 85, note 5). They appear on a 17th century ark from Krakow in the collection of the Heichal Shlomo Museum. http://kng58.org.il/sliding-doors/, accessed on 16 December 2019.

20 Known in the Polish and Yiddish literature as the "Lemberg" Haggadah because it was originally to be dedicated to a group of Jews in Lvov who were sponsors of Szyk (Sabar 2008a, p. 54). He even made a contract with the community of Lvov to publish the Haggadah, see (Ungar 2008, pp. 190, 198-99).

21 Forty of the drawings are dated 1935. All of the watercolor and gouache paintings were done by Szyk on paper (Ungar 2008, p. 209).

22 The Bezalel Narkiss Index of Jewish Art, ID 169143-169144.

23 Griffins holding the crown are on the ark from Druya (Yaniv 2017, pp. 117-18); they appear as substitutes for the cherubim on the ark of Yarishiv (ibid., pp. 166-67); Yaniv concludes that "the griffin, an imaginary creature which combines a lion's body with an eagle's head and wings was a suitable replacement [for the cherubim]" (ibid., p. 169).

24 For a complete discussion, see (Sabar 2008a, pp. 33-170).

25 Also reproduced in (Ungar 2017a, p. 58, fig. 25).

26 Reproduced in (Sabar 2008a, p. 61).

27 For one such example, see (Nashman Fraiman 2006).

28 The Forest Hills Jewish Center 1931-1981, unpaged. 
described by Rabbi Bokser as "doves, the symbols of peace". ${ }^{29}$ Doves were already used by Szyk in his frontispiece to Volume 10 of the 1943 Universal Jewish Encyclopedia, published belatedly in 1948, but there they are more naturalistic in their appearance (Landman 1948, frontispiece). ${ }^{30}$ (Figure 12) This frontispiece exemplifies Szyk's attention to detail and his creation of unique symbols. Besides doves, he depicts a parrot and a frog, which are not at all typical Jewish motifs! Dedicated to the "Hallowed Memory of Europe's Martyred Jews", the image was accompanied by the following text written by Szyk: "It portrays the Jews as defiant and unafraid, marching confidently and dauntlessly into the future. In his arms he bears his most precious and eternal possession, the portable fatherland, the Torah. Draped round his shoulders is the mantle of royalty that eclipses the yellow badge he perforce must wear. In his right hand is the shepherd's staff of leadership; in his left, the jester's bauble betokening his unfailing sense of humor in the midst of adversity. Accompanied by the stage of eternity, he serenely goes his way in scorn of the bloated toad of pride, the arrogant parrot of vanity and the hissing serpent of treachery, coiled around the tree of life. Beneath is the Shield of David, bearing the scales of justice and the doves of peace, with its crest of the crown of a good name and its supporting lions of Judah. In the background are the brilliant clouds of hope and at the base are the grapes of fertility that promise a happier future" (ibid.). ${ }^{31}$ This drawing and accompanying text illustrate Syzk's sensitivity to the plight of European Jewry, at the same time showing his emphasis on detail and symbols, coupled with a free-wheeling approach to iconography, which is also seen in the ark.
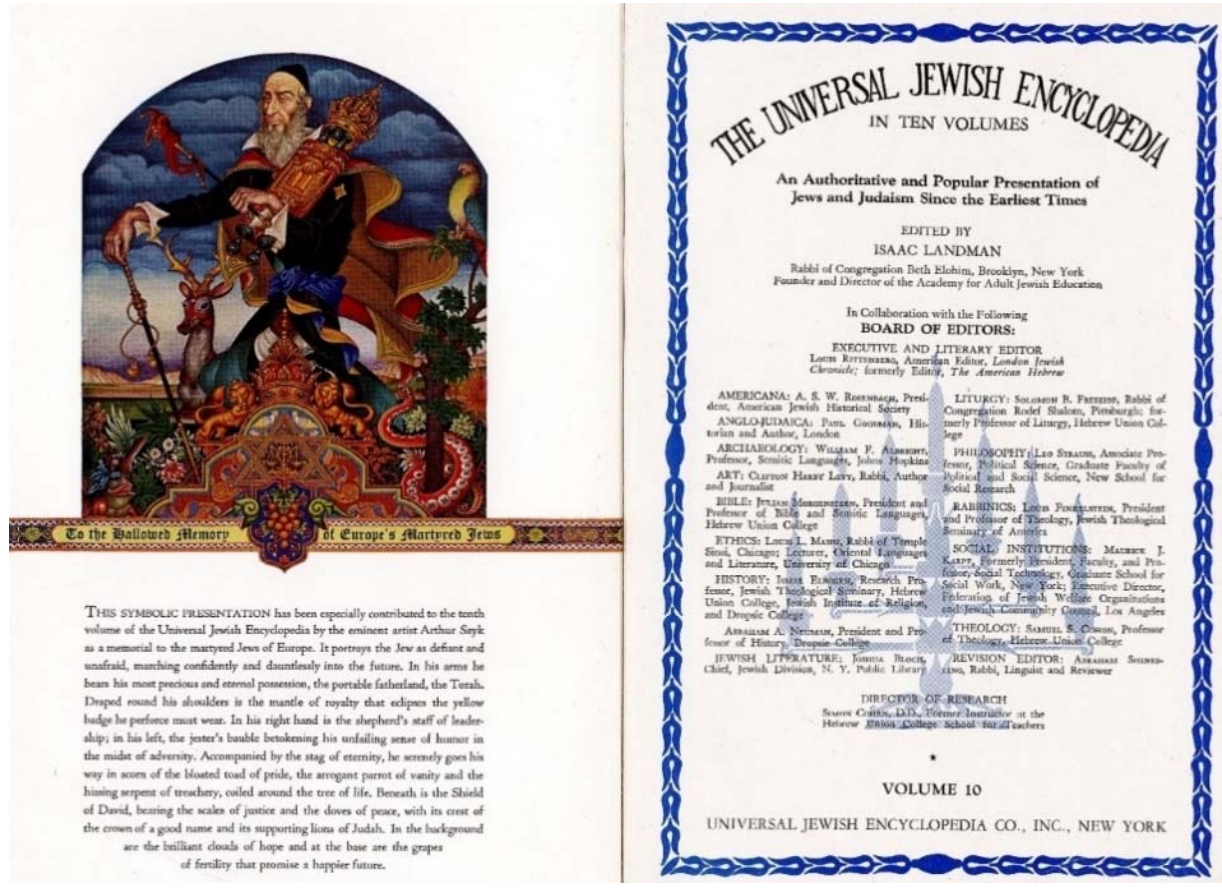

Figure 12. Frontispiece to Volume 10 of the 1943 Universal Jewish Encyclopedia, 1948.

29 From an explication of the ark in Bokser's papers at the Jewish Theological Seminary, "An Interpretation of Our Ark," Ben Zion Bokser Rabbinical Papers, The Library of the Jewish Theological Seminary, New York, NY, ARC.1000.026, (Box 17, Folder 5).

30 Szyk has more naturalistic doves also in his dedication to King George VI. See (Sabar 2008a, p. 57).

31 Although listed as being copyrighted in 1948, it seems that some of the entries were only updated to 1943; so, for instance, the Warsaw Ghetto uprising is not mentioned in the entry for Warsaw, nor is the end of World War II. 
Another original motif of Szyk's are his tablets of the Ten Commandments (Figure 11), which are an extremely common element in western Torah arks (Sarfatti 1990). ${ }^{32}$ Szyk signifies the commandments by their first letter instead of by the first two words, and this motif already appears in the Haggadah (Sabar 2008a, p. 131), as well as in his illustrations for Pathways Through the Bible (Figure 13).

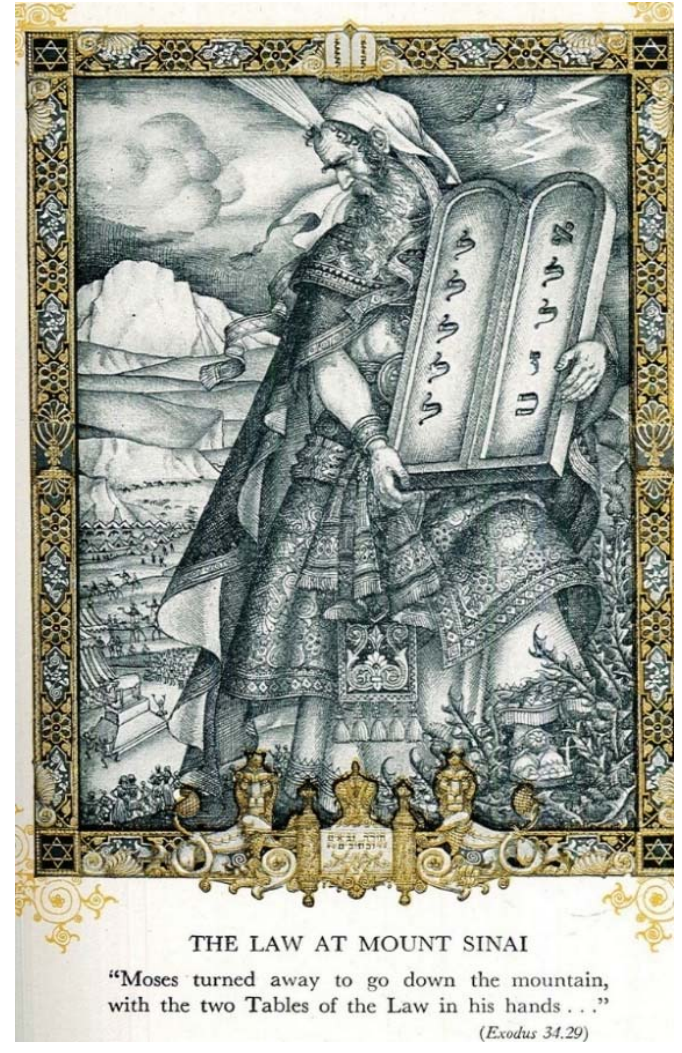

Figure 13. Moses, Pathways Through the Bible (Cohen 1946, facing p. 100).

Perhaps the most puzzling element of the ark is Szyk's interpretation of the symbols of the twelve tribes $^{33}$ (Figure 14), which adorn the doors of the ark (as well as the doors of the ark of a smaller chapel $^{34}$ ) downstairs. There has yet to be a comprehensive article about the plethora of depictions, varied both in iconography and arrangement, of the twelve tribes in Jewish art over the centuries. ${ }^{35}$ Szyk based his depictions partially on Jacob's blessing to his sons in Genesis 49 and also incorporated elements from BeMidbar Rabba (the Midrash) on Numbers 2:2 and Deuteronomy 33. ${ }^{36}$

The symbols on the right side are fairly easy to interpret, as their depictions are based directly on Genesis, chapter 49, Exodus or the Midrash. There are no labels to the symbols.

32 For a full list of articles that discuss the Ten Commandments, in both Jewish and Christian art, see (Sabar 2008b, p. 394, note 70). Sabar discusses the Ten Commandments in the synagogue of Amsterdam and in the work of Rembrandt on pages 393-402.

33 It is important to note that the use and diffusion of the symbolism of the twelve tribes appears already on Italian Ketubbot of the 17th century, as well as on the walls of painted European synagogues in the 19th century. For a discussion of the imagery of the tribes, see (Sabar 1987, pp. 181-92; Sabar 1998, pp. 308-10) and notes there. According to Sabar (2003, p. 204), the earliest extant depiction of the twelve tribes in a Jewish context has survived on an illuminated marriage contract from Verona, dated to 1695.

34 The doors of the "Little Synagogue" ark are carved from wood, The Forest Hills Jewish Center 1931-1981, unpaged.

35 Mishori (2019) article is the most recent treatment of the tribes in Israeli art, but it is far from complete, and a complete discussion of this imagery is outside the scope of the present article.

36 For the Hebrew, see (Shinan 2015, p. 101); for English, see (Slotki 1939, p. 30). 


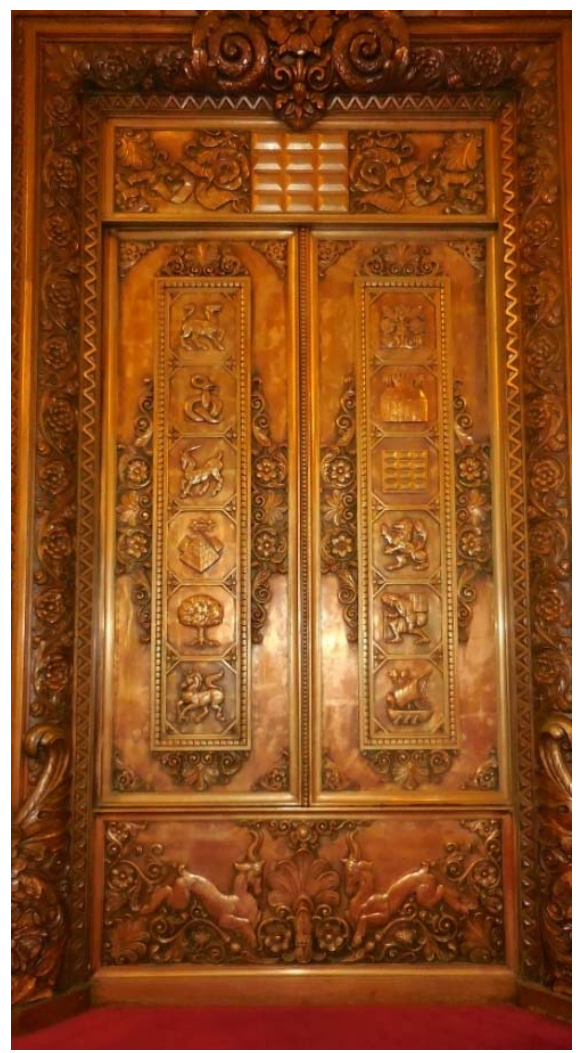

Figure 14. Detail, ark doors.

Starting from the upper right, the depictions appear as follows:

Reuven is depicted as a flowering plant (Midrash on Numbers);

Simeon as the gate of Shechem (Midrash on Numbers);

Levi-by the Priestly Breastplate (in Hebrew, Hoshen) (Exodus 28:15-21);

Judah by a Rampant Lion (Genesis 49:9);

Issachar by man in ancient garb, hunched over with basket on back (Genesis 49:15);37

Zebulun by a Ship (Genesis 49:13).

Having said that, the order is not clear, because it is not according to the birth order of the sons, the order of the verses in the Bible, nor the order of the sons in Jacob's blessing.

The depictions on the left door are more challenging, because neither the order nor the iconography of all of the symbols are readily apparent.

Starting from the upper left, the following depictions appear:

Benjamin—wolf (Genesis 49:27); ${ }^{38}$

Dan, a snake (Genesis 49:17);

Naftali a hind (Genesis 49:21).

37 Sabar (2008a, p. 152, note 109) suggested that Szyk changed the traditional symbolism of Issachar as a donkey, to suit the message of the Haggadah, but the description is in fact based on the literal meaning of the verse ("For he saw a resting-place that it was good, and the land that it was pleasant; and he bowed his shoulder to bear, and became a servant under task-work") and already appears in earlier works of Szyk's (). See also note 46, below.

38 Benjamin's symbol looks like a horse, but it may have been a technical problem of a misinterpretation of the drawing by Szyk. 
The last three depictions are a pyramid with a crown on top, below that, a tree, and below that, what appears to be a unicorn. ${ }^{39}$ The remaining tribes are Gad, Asher, and Joseph, who is often represented by his sons, Ephraim and Manasseh.

The main source of inspiration for Szyk's tribal depictions is a book illustration by Ephraim Moses Lilien (1874-1925), who taught for only six months at Bezalel at its founding, but continued to be an important influence for the school until 1929. ${ }^{40}$ Among one of his many book commissions, Lilien illustrated the work of poems by Morris Rosenfeld (1862-1923), Lieder des Ghetto, that was translated from Yiddish into German, and published in $1902 .{ }^{41}$ In the book, the images of the twelve tribes frame the poem "Juda" (Figure 15), which speaks of the longing for the "Heimat", the homeland. The tribes are not mentioned specifically in the poem (Rosenfeld 1902, pp. 63-64). ${ }^{42}$ In a review of the book at the time, published in the American Hebrew, there is no specific reference to that particular poem or its decoration. ${ }^{43}$

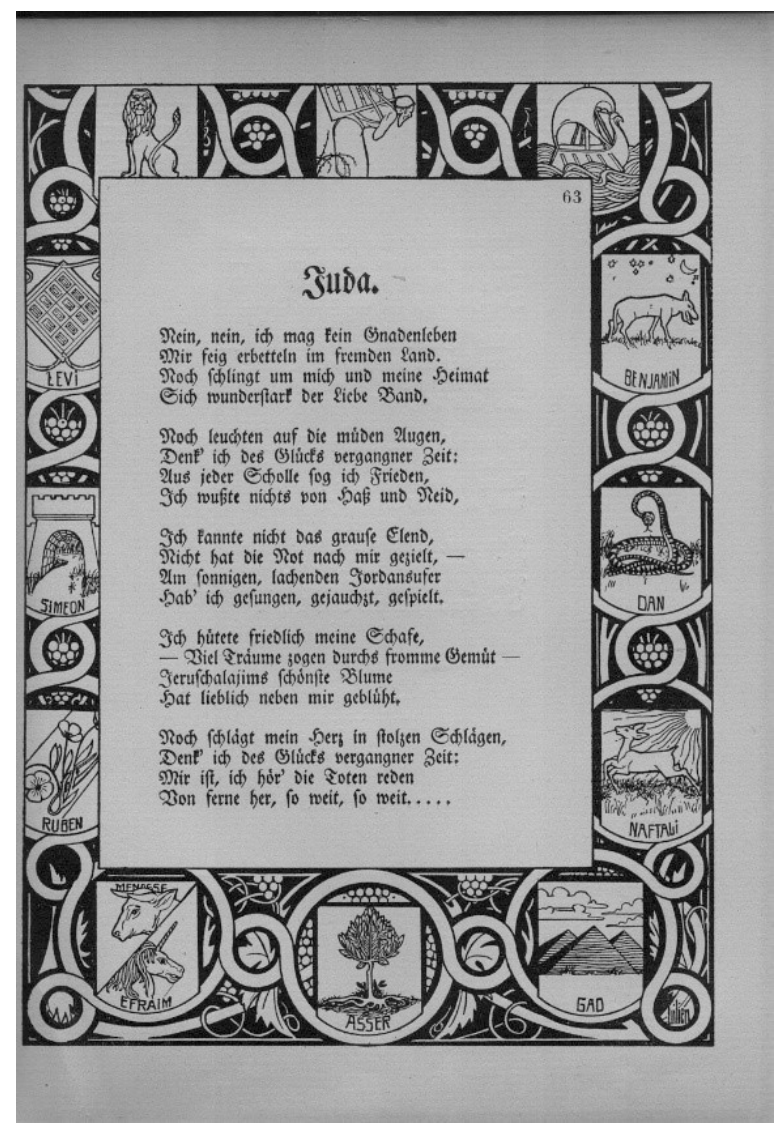

Figure 15. E.M. Lilien, illustration for the poem "Juda" from Morris Rosenfeld, Lieder des Ghetto, translated by Berthold Feiwel (Berlin: Seeman, 1902), p. 63.

39 Sources for some of this imagery can also be found in Szyk's other works. The exact same tribal imagery appears in an early work for a Haggadah depicting the Pharaoh's maid saving the baby Moses from the Nile (Ungar 2008, p. 178, fig 50), as well in later works, such as in in the plate Israel, from the Visual History of the Nations, published in 1948.

40 I am grateful to Sergey Kravtsov for pointing this out to me.

41 Lilien's depiction of the tribes may predate this version, as seen in his design for the cover of the Jewish National Fund Golden Book, ca. 1902 (Mishori 2019, p. 225). Lilien was consistent in his depictions, but Mishory does not analyze specific motifs. This article is the most recent treatment of the tribes in Israeli art.

42 The frame was reused again, later in the book, for other poems (Sephirah, pp. 78-79 and Das Wunderschiff, pp. 128-129), with no relationship to the content.

43 Unsigned article, "Rosenfeld's Poetry in German Form, illustrated by Lilien”, in the American Hebrew, vol. LXXII, no. 16, 6 March 1903, pp. 530-31, cited by Kabakoff (2003, p. 70). 
Szyk arranged the tribes differently from Lilien. In Lilien's work, Reuven, the first-born, appears in the lower left side of the frame, and then the order continues up and to the right. Szyk uses the same order exactly, but starts in the upper right, going down and then starting again in the upper left side. The explanation for this order of the tribes may be tied to the biblical verses from Exodus 1:1-4, which describe the descent into Egypt.

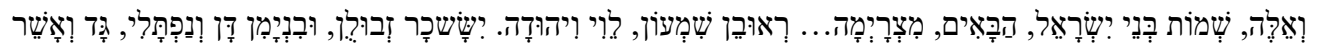

Joseph is not mentioned in this list, since he had previously come to Egypt on his own. Lilien added Ephraim and Manasseh, who, as the sons of Joseph, would have a portion in the land, at the end of his depiction. Lilien depicts Gad as a pyramid, Asher as a tree, and Manasseh and Ephraim as a bull and a unicorn, respectively. Gad's depiction is based on Genesis 49:19, and the usual depiction is of a tent. ${ }^{44}$ The depiction of Asher as a tree comes from the midrash on Numbers 2:2, as cited above. The depictions of Manasseh and Ephraim show a bull for Manasseh and a unicorn ( $\left.r e^{\prime} e m\right)$, interestingly enough, for Ephraim. This is based on Moses' blessings to the tribes in Deuteronomy 33:17. If anything, according to the midrash, Manasseh is symbolized by the unicorn, not Ephraim. The biblical re'em, associated by the rabbis with Manasseh, is a horned animal, which, when seen from the side, might look like a unicorn (Bamidbar Rabba 2:7). Interestingly, in the German translation of the Bible, based on the Vulgate, re'em is translated as a unicorn, and this most likely explains Lilien's depiction. ${ }^{45}$ Szyk, who copied all of the other motifs in his own style, without labeling them, only depicted one of Joseph's sons-as the unicorn. To return to the verse, the order of the text indicates the importance of the mothers, as is reflected in the order of the symbols on the ark: Leah's sons appear on the right-hand door, while Rachel's youngest son, Benjamin, is on the top left. They are followed by the four sons of the handmaidens, again in order of importance: the sons of Bilhah (Rachel's handmaiden), followed by the sons of Zilpah (the handmaiden of Leah.) The last medallion is therefore somewhat ambiguous. The discrepancies between the traditional texts and the depiction of the tribes as they appear on the ark may be explained by the fact that Szyk sometimes played fast and loose with Jewish iconographical and textual traditions, perhaps due to his prodigious output and its attendant pressures. In his Haggadah, Szyk depicts the story of Exodus 7:10 in a manner at variance with the actual text:

So Moses and Aaron came before Pharaoh and did just as the LORD had commanded: Aaron cast down his rod in the presence of Pharaoh and his courtiers, and it turned into a serpent.

Instead of Aaron turning his staff into a snake, it is Moses who does so! ${ }^{46}$ To return to the arrangement, Lilien's choice of the order of the tribes as they descended into Egypt speaks of the consciousness of living in the Diaspora, which would also apply to the poem "Juda" by Morris Rosenfeld that was framed by these symbols. Did Szyk just copy them slavishly, or was there another meaning hidden here, particularly because he omitted Manasseh, and since we know that Szyk commonly employed symbolism in his works?

To confuse matters, around the same time, on the first-day issue envelope for two stamps Szyk designed for the nascent State of Israel, he also depicted the tribes, whose symbols are the same as those on the ark, but the order here is different. Moreover, Szyk labeled the tree as Joseph (which would be congruent with Genesis 49:22: "Joseph is a fruitful bough ..."), but the pyramid as Asher and the unicorn as Gad, which are clearly at odds with all traditional interpretations. ${ }^{47}$ It would also be interesting to compare his imagery with the imagery of a fellow artist from Lodz, Ze'ev Raban,

44 Sabar (2008a) suggested that the usual symbolism of the tent for Gad was replaced with the pyramid, to fit in with the theme of the Haggadah (p. 170, note 109). However, we now see that it was a direct copy from Lilien.

45 See (Brown et al. 1951, “ראם", p. 910).

46 Mentioned by Sabar (2008a, pp. 78-79) and stated by Irvin Ungar at his lecture "Freedom Illuminated-Understanding the Szyk Haggadah", at the National Library in Jerusalem, 8 November 2018.

47 Reproduced in (Ungar 2017a, p. 215, fig 175), issued 31 August 1950. 
who designed the doors of the Bikur Holim synagogue in 1925. Raban's imagery has some overlap with Szyk's, but also has not been completely analyzed. What is significant is that Raban's order is clearer-the tribes are labeled and arranged by the order of their birth. ${ }^{48}$ In short, with both Szyk and Rabbi Bokser's passing, this question of Szyk's intent in the ark door design remains partially unanswered.

Last but not least, one of the remarkably innovative themes of this ark is freedom. This is hardly surprising in the wake of World War II and in light of Szyk's oeuvre, particularly the Haggadah and his extensive work as a caricaturist during the war, and the fact that Bokser served as a military chaplain during the war. Three main elements convey this theme. As mentioned above, two doves are depicted on the ark. However, the heraldic position and appearance of these doves are more reminiscent of Szyk's depictions elsewhere of Polish and American eagles. ${ }^{49}$ Although eagles often appear on European carved arks, ${ }^{50}$ for Szyk, they also symbolized freedom in the wake of World War II, which would also be congruent with Bokser's message. In addition, the unique choice of texts around the top of the ark and the accompanying bronze menorot on the bima (the raised platform before the ark), which have the word "herut" (freedom) emblazoned on their bases (Figure 8), emphasize the theme of freedom. This echoes the verse that surrounds the entire top of the ark, as mentioned above, which has a play on the words "engraved" and "freedom". The choice of these texts, which are not traditional, as explained by Bokser in a text found in his archive ${ }^{51}$ entitled "An Interpretation of Our Ark", was that the ark "proclaims the rabbinic doctrine of the role of the Ten Commandments in civilization, as the pathway to human freedom". Szyk's connection to freedom was more political. On 4 July 1950, a gathering was held in Szyk's community of New Canaan, Connecticut, to honor the publication of his illustrated Declaration of Independence. The speaker at the event hailed Szyk "as one of the world's great free men who has dedicated his life and art to the preservation of freedom". ${ }^{52}$

Exactly how immersed Rabbis Pressman and Bokser were in the design of the synagogue and, specifically, the Torah ark, is not documented. In general, not all rabbis were involved in the postwar boom of synagogue building in the US (Kampf 1966, p. 51). I have been unable to locate any design requests or specifications in correspondence between Szyk and the two rabbis, or with members of the congregation. ${ }^{53}$ Interestingly enough, Pressman, in his memoirs, writes that, in his career, he designed three Torah arks. However, it is not clear whether they were all for his community in Los Angeles (Pressman 2001, p. 352). ${ }^{54}$

48 On the right door are labeled medallions for Reuven, Simeon, and Levi, together with Judah, Issachar, Zebulun, and Dan. On the left door are symbols for Naftali, Gad, Asher, Benjamin, Ephraim, and Menasseh. Mentioned in Shinan editor, Parashat Veyechi, 12, 1/2001, unpaged in Nehardea, Sheets in the weekly Torah Portion of the Hebrew University (Nehardea, Dapei Parashat HaShavua shel HaUniversita Hivrit).

49 Szyk depicted the Polish eagle in his cycle on the Statute of Kalisz, published in 1928, https://www.polin.pl/en/event/thestatute-of-kalisz-the-750th-anniversary-of-the-first, accessed on 6 December 2019, and also in the Visual History of Nations Series (New Canaan, 1946), an ambitious project to depict sixty countries. Only nine were every completed. He depicted the American Eagle in 1945 as part of this same series. http://www.loc.gov/exhibits/szyk/szyk-ex.html\#obj2, accessed on 6 December 2019.

50 Yaniv (2017) discusses the motif of the eagle in several places: p. 101 and in her discussion of the animal imagery of perek shirah, pp. 112-28.

51 Ben Zion Bokser Rabbinical Papers, The Library of the Jewish Theological Seminary, New York, NY, ARC.1000.026, (Box 17, Folder 5).

52 Cited by (Ungar 2017b, pp. 25-26).

53 Neither at the synagogue nor in Bokser's archive at the Library of the Jewish Theological Seminary. Pressman does not have an archive at the Jewish Theological Seminary in NYC. Bokser was only decommissioned in April 1946. Pressman moved to Los Angeles in 1948, as an assistant rabbi at Temple Sinai and he served as the congregational rabbi of Temple Beth Am from 1950 until his retirement (Bnai Brith Messenger, 1 October 1948, p. 71; The Jewish Biographical Bureau 1980, p. 380). He was a prominent Jewish leader for the rest of his career, often speaking at political events. https://www.tbala.org/about/our-history, accessed on 16 December 2019.

54 The ark in use, up until the latest renovation, was modeled after the Torah case given to Harry Truman by Chaim Weizmann and designed by Ludwig Wolpert of the Bezalel School. https:/www.trumanlibrary.gov/photograph-records/2003-290, accessed on 16 December 2019. In 1966, a wall in memory of the Holocaust was created in the sanctuary at Pressman's initiative. If anything, this may speak of the influence of Bokser on Pressman. https://www.haaretz.com/us-news/.premium1-a-s-mostly-forgotten-holocaust-wall-1.5464671, accessed on 16 December 2019. 
The art historian Avram Kampf lamented the fact that "the tragedy of World War II had a surprisingly small influence on the artworks placed on or designed for synagogues" (Kampf 1966, p. 65). Nevertheless, it seems that Rabbi Bokser's vision and life experience definitely inspired elements of the Forest Hills ark. It is possible that Bokser, who was born in Luboml, in 1907, and came to the US in 1920, had some recollection of the synagogue decoration there. ${ }^{55}$ According to one account of the synagogue in Luboml, "all along the wall, under the windows, and on the retaining wall of the women's gallery on the western side were pictures of various scenes-the primeval ox and the Leviathan, musical instruments from the Temple, and the twelve tribes. Only the eastern wall was pure white, without pictures or adornments, and against this background stood the magnificent Holy Ark, with the two traditional lions on either side, as well as engravings of various tree branches". ${ }^{\prime \prime}$ More importantly, in his Kol Nidre message of 1945, reprinted in the synagogue newsletter, Rabbi Bokser stated his overall mission for the new building: "Because we shall build it in these times, I should like to see in it an answer to the dehumanizing forces released by modern technology whose deadly peril has been dramatized in this war. I should like to see in it a fitting memorial to those fallen, whether on the fields of battle or in Europe's death camps. And I should like to see in it, too, a memorial to those historic synagogues that perished in the flames of Nazi vandalism, but whose spirit lives on, and must find in us a new vindication". ${ }^{57}$ In fact, besides all of the details already mentioned, if one looks at the overall form of the ark, it is in some way reminiscent of the shape of many of the carved-wood arks of Eastern Europe that were no more. ${ }^{58}$ In this way, the community of Forest Hills was singularly prescient at that time in commemorating the lost synagogues of Europe and, by extension, the lost communities. ${ }^{59}$ There is no doubt that the ark's design was a synergy between Rabbi Bokser and Szyk's ideas, and their views complemented each other and came together in the unique design of the ark.

The ark was not without its critics. The exterior style of the synagogue was considered contemporary in style ${ }^{60}$ but clearly the ark was not designed in a modern idiom. Both Stephen Kayser and others felt that Szyk's ark was not suitable for its architectural surroundings. ${ }^{61}$

Szyk passed away in 1951. He had already suffered one heart attack at the beginning of the year, and the second one proved fatal. Was his death hastened by the fact that, at the beginning of the 1950s, his name was published on a list of individuals associated with "un-American" organizations? As a newly minted US citizen, Szyk must have been desolate that he, with his fervor for democracy and freedom, the same fervor that brought him so much fame in the 1940s, was blacklisted. ${ }^{62}$ It would seem that the reason for this was the program cover he illustrated for an organization that was

55 A short page of his memories, "Our Shtetl”, appears in the English translation of the Luboml Yizkor Book (Libovner Voliner Benevolent Society 1977, p. 114).

56 Other accounts mention depictions of the Holy Temple and the Zodiac (Hetman 1977, pp. 146-47; Kandelshteyn 1977, p. 160).

57 September 1945 issue of The Message, p. 1, Ben Zion Bokser Rabbinical Papers, The Library of the Jewish Theological Seminary, New York, NY, ARC.1000.026, (Box 16, Folder 4).

58 The shape of this Torah Ark does not at all resemble the Torah ark depicted in Szyk's Haggadah but is more similar to the frontispiece design of the Haggadah. In an album commemorating the 50th anniversary of the synagogue, The Forest Hills Jewish Center 1931-1981 (in the collection of the synagogue-unpaged), the shape was likened to a breastplate. However, it is more likely to be based loosely on the form of European wooden synagogue arks that are wide at the bottom and taper off at the top, often topped with a crown. See, for instance, the Torah Ark of Vyzuonos (Yaniv 2017, p. 235) and of Lukiv (ibid., p. 246).

59 Several more contemporary synagogues have tried to hearken back to the wooden synagogues of Eastern Europe, for instance, the Hampton Synagogue in Westhampton Beach, New York (Gruber 2003, pp. 201-02).

60 However, it was unlike many other synagogues being built at that time, such as the synagogues designed by Erich Mendelsohn and Percival Goodman. For more on Goodman, see (Cohen 1993/1994). Most, but not all of the 50 synagogues he was involved in belonged to the Reform Movement, which, not surprisingly, embraced the modernist visual idiom. At least two of Mendelsohn's designs were for Conservative congregations, The Park Synagogue of Cleveland Heights and Bnai Amoona of St. Louis (now a center for the arts, https://www.cocastl.org/createourfuture/historic-mendelsohn-building/, accessed on 8 December 2019).

61 Kayser does not mention Szyk or the synagogue by name; he simply hints at them: "For example, at one of our new synagogues, after the rather modern structure was completed, an artist was commissioned to design an Aron Kodesh. The artist's general inclination is toward renewal of certain picturesque features in Jewish pictorial at and whose thinking is much more in terms of minute details than in monumental structures" (Kayser 1951, p. 16); Schack (1956, p. 156) mentions Szyk by name.

62 Szyk became a United Stated citizen in 1948 (Ansell 2004, p. 227). 
connected to the Soviet Union in 1943, when the United States and the Soviet Union had common cause (Ansell 2004, pp. 230-32; Luckert, pp. 107-09). ${ }^{63}$ The subsequent change in attitude toward the Soviet Union in the postwar United States resulted in Szyk's name being added to a list of prominent Americans to be investigated for belonging to an organization considered subversive by the Attorney General. Szyk died before he was called to testify (Freudenheim 2017, plates 50, 94). The funeral was, of course, held at the Forest Hill Jewish Center (Ansell 2004, p. 233).

As for the ark-once at the center of a thriving Conservative Jewish community, the sanctuary and the Forest Hills Jewish Center building are in the process of being "re-purposed". The community can no longer afford the upkeep of the large and, by now, old building. As of this writing, original plans to demolish the synagogue have been put on hold. ${ }^{64}$ In any case, the ark will either be retained or find its way to a new home, possibly a museum. ${ }^{65}$

To conclude, an analysis of Arthur Szyk's Torah ark reveals his originality, creativity, and richly deserved stature as an innovator in Jewish art, albeit not in a modern idiom. The inevitability of change in contemporary life in general and in the demographics of Jewish communities in particular underscores the vital importance of the documentation of works of Jewish art as a means of sharing the treasures of Jewish cultural heritage with future generations.

Funding: This research received no external funding.

Acknowledgments: The author wishes to thank Deborah Gregor, Executive Director, and the Rabbis and the Board of the Forest Hills Jewish Center for their essential help and permission to use the images and material that appear here, and Rabbi Jerry Schwarzbard of the Library of the Jewish Theological Seminary in New York for his assistance. This paper was initially presented at the International Workshop "Framing the Sacred: Shrines in European Architecture", which was held in June 2018, at Bar Ilan University, thanks to Professor Ilia Rodov. All photographs are by the author and used courtesy of the Forest Hills Jewish Center, unless otherwise specified.

Conflicts of Interest: The author declares no conflict of interest.

\section{References}

Ansell, Joseph. 2004. Arthur Szyk, Artist, Jew, Pole. Oxford: Littman Library of Jewish Civilization.

Bernstein, Philip S. 1945. Jewish Chaplains in World War II. American Jewish Yearbook 47: 180.

Brown, Francis, Samuel Rolles Driver, and Charles Augustus Briggs. A Hebrew and English Lexicon of the Old Testament. Oxford: Clarendon Press.

Carmin, Itzhak, ed. 1955. World Jewish Register. New York: Monde, pp. 631-32.

Cohen, Mortimer J. 1946. Pathways Through the Bible. Philadelphia: The Jewish Publication Society.

Cohen, Mortimer J. 1946/1947. Szyk-Illustrator of Jewish Books. Jewish Book Annual V: 70-77.

Cohen, Evelyn L. 1993/1994. The Tabernacle in the Wilderness: The "Mishkan" theme in Percival Goodman's modern American synagogues. Jewish Art 19/20 (1993-1994): 44-55.

Freudenheim, Tom. 2017. Arthur Szyk: Immigrant as Quintessential American Patriot. In Arthur Szyk, Soldier in Art. Edited by Irvin Ungar. London: Giles, pp. 83-95.

Gruber, Samuel D. 2003. American Synagogues: A Century of Architecture and Jewish Community. New York: Rizzoli.

Hetman, Yakov. 1977. The Great Synagogue. In Libovner. New York: Ktav, pp. 145-48.

Israelowitz, Oscar. 1992. Synagogues of the United States. Brooklyn: Israelowitz Publishing.

Kabakoff, Jacob. 2003. E.M. Lilien as interpreter of Morris Rosenfeld's Ghetto Poems. Yiddish 13: 65-77.

Kampf, Avram. 1966. Contemporary Synagogue Art. Philadelphia: Jewish Publication Society of America.

Kandelshteyn, Shimon. 1977. Candid Snapshots of our Town. In Libovner. New York: Ktav, p. 160.

Kayser, Stephen. 1951. The Synagogue Interior Today. Conservative Judaism VII: 13-19.

Landman, Isaac, ed. 1948. The Universal Jewish Encyclopedia. New York: Universal Jewish Encyclopedia Co., vol. 10.

63 Szyk was to be investigated for activities alongside dignitaries such as Einstein. See (Freudenheim 2017, pp. 93-94).

64 https://patch.com/new-york/foresthills/forest-hills-jewish-centers-redevelopment-put-hold-report, accessed on 10 December 2019.

65 Conversation with the Center's Executive Director, Deborah Gregor, April 2018. 
Libovner Voliner Benevolent Society. 1977. Luboml, the Memorial Book of a Vanished Shtetl. New York: Ktav. Luckert, Steven. The Art and Politics of Arthur Szyk. Washington: United States Holocaust Memorial Museum. Mendelsohn, Ezra. 2010. Arthur Szyk. Artist, Jew, Pole. European Journal of Jewish Studies 4: 324-28. [CrossRef] Mishori, Alec. 2019. The Twelve Tribes of Israel: From Biblical Symbolism to Emblems of a Mythical Promised Land. In Secularizing the Sacred Aspects of Israeli Visual Culture. Brill's Series in Jewish Studies; Leiden: Brill, vol. 65 , pp. 209-43.

Nashman Fraiman, Susan. 2006. Joy and Gladness, Happy Festivals for the House of Judah: A unique parochet from Alessandria Della Paglia. Ars Judaica; the Bar-Ilan Journal of Jewish Art 2: 151-62.

Pressman, Jacob. 2001. Dear Friends A Prophetic Journey through Great Events of the 20th Century. Hoboken: Ktav. Rosenfeld, Morris. 1902. Lieder des Ghetto. Translated by Berthold Feiwel. Berlin: Seeman.

Roth, Cecil. 1969. A Bibliographical Note on the Szyk Haggadah. Studies in Bibliography and Booklore IX: 50.

Sabar, Shalom. 1987. The Beginnings and Flourishing of "Ketubbah" Illustrations in Italy. Ph.D. dissertation, UCLA, Los Angeles, CA, USA. unpublished.

Sabar, Shalom. 1998. Messianic aspirations and Renaissance urban ideals: The image of Jerusalem in the Venice Haggadah, 1609. In The Real and Ideal Jerusalem in Jewish, Christian and Islamic Art; Studies in Honor of Bezalel Narkiss on the Occasion of His Seventieth Birthday. Special issue of the Journal of Jewish Art, 23/24, 295-321. Edited by Bianca Kühnel. Jerusalem: Hebrew University, Center for Jewish Art.

Sabar, Shalom. 2003. The harmony of the cosmos: The image of the ideal Jewish world according to Venetian "kettubah" illuminators. In I beni Culturali Ebraici in Italia; Situazione Attuale, Problemi, Prospettive e Progetti per il Futuro. Edited by Mauro Perani. Ravenna: Longo Editore, pp. 195-215.

Sabar, Shalom. 2008a. The Historical and Artistic Context of the Szyk Haggadah. In Freedom Illuminated: Understanding The Szyk Haggadah. Edited by Byron L. Sherwin and Irvin Ungar. Burlingame: Historicana, pp. 33-170.

Sabar, Shalom. 2008b. Between Calvinists and Jews: Hebrew script in Rembrandt's art. In Beyond the Yellow Badge; Anti-Judaism and Antisemitism in Medieval and Early Modern Visual Culture. Edited by Mitchell B. Merback. Leiden: Brill, pp. 371-404.

Sarfatti, Gad Ben Ami. 1990. The Tablets of the Law as a Symbol of Judaism. In The Ten Commandments in History and Tradition. Edited by Ben-Zion Segal and Gershon Levi. Jerusalem: Magnes Press, pp. 383-418.

Schack, William. 1956. Modern Art in the Synagogue II. Commentary 21: 152-61.

Sherwin, Byron L, and Irvin Ungar, eds. 2008. Freedom Illuminated: Understanding The Szyk Haggadah. Burlingame: Historicana. Shinan, Avigdor. 2015. Sefer Ha'Aggada. Compiled by CH.N. Bialik \& Y.Ch. Ravnitzky. Edited with a New Commentary by Avigdor Shinan. Or Yehuda: Dvir. (In Hebrew)

Judah Slotki, trans. 1939, Midrash Rabba Numbers I. London: Soncino.

Szyk, Arthur. 2011. The Haggadah. Translation and Commentary by Byron L. Sherwin with Irvin Ungar. New York: Abrams.

Ungar, Irvin. 2008. Telling the Story: A History of the Szyk Haggada. In Freedom Illuminated: Understanding The Szyk Haggadah. Edited by Byron L. Sherwin and Irvin Ungar. Burlingame: Historicana, pp. 121-239.

Ungar, Irvin, ed. 2017a. Arthur Szyk—Soldier in Art. Burlingame: Historicana.

Ungar, Irvin. 2017b. Behind the Great Art and the Great Messages Stands Arthur Szyk, the Great Man. In Arthur Szyk —Soldier in Art. Edited by Irvin Ungar. Burlingame: Historicana, pp. 11-29.

The Jewish Biographical Bureau. 1980. Who's Who in American Jewry. Los Angeles: Standard.

Wischnitzer, Rachel. 1955. Synagogue architecture in the United States. Philadelphia: Jewish Publication Society.

Yaniv, Bracha. 2006. Praising the Lord: Discovering a Song of Ascents on Carved Torah Arks in Eastern Europe. Ars Judaica 2: 83-102.

Yaniv, Bracha. 2017. The Carved Wooden Torah Arks of Eastern Europe. Oxford: Littman.

(C) 2020 by the author. Licensee MDPI, Basel, Switzerland. This article is an open access article distributed under the terms and conditions of the Creative Commons Attribution (CC BY) license (http://creativecommons.org/licenses/by/4.0/). 